\title{
Class and Politics in Wilhelmine Germany: The Center Party and the Social Democrats in Württemberg
}

\section{Citation}

Blackbourn, David. 1976. Class and politics in Wilhelmine Germany: The center party and the social democrats in Württemberg. Central European History 9(3): 220-249.

\section{Published Version}

doi:10.1017/S0008938900018227

\section{Permanent link}

http://nrs.harvard.edu/urn-3:HUL.InstRepos:3629314

\section{Terms of Use}

This article was downloaded from Harvard University's DASH repository, and is made available under the terms and conditions applicable to Other Posted Material, as set forth at http:// nrs.harvard.edu/urn-3:HUL.InstRepos:dash.current.terms-of-use\#LAA

\section{Share Your Story}

The Harvard community has made this article openly available. Please share how this access benefits you. Submit a story.

Accessibility 


\title{
Class and Politics in Wilhelmine Germany: The Center Party and the Social Democrats in Württemberg
}

\author{
DAVID G. BLACKBOURN
}

$\mathrm{B}$

ETWEEN 1890 and 1914 the Center party was, in Friedrich Naumann's words, "the measure of all things" in German politics. ${ }^{1}$ Throughout this period it possessed a quarter of the seats in the Reichstag, and held the balance of power between left and right. Its importance from the standpoint of Bismarck's successors as chancellor stemmed from the electoral and parliamentary decline of the National Liberals and Conservatives, the parties which had formed the Kartell through which Bismarck governed the Reichstag. After 1890 these no longer commanded a majority, and other parties had to be won over by the government. ${ }^{2}$ With the Social Democrats permanently hostile, this narrowed the government's choice down to the Progressives and Center, either of which would give the Kartell parties a majority, and both of which were to be used to this effect. However, the Progressives were used only sparingly (above all during the Bülow Bloc of 1907-9) because of their increasing shift to the left. The historic reason for this was the party's antimilitarism; and this move to the left was reinforced by fears among Progressive leaders that their supporters might otherwise defect to the Social Democrats. The Center was therefore the only alternative. ${ }^{3}$ For most of the Wilhelmine period successive

I should like to thank Geoff Eley, Joseph Lee, and Norman Stone for their criticisms and advice.

1. F. Naumann, Die politischen Parteien (Berlin, 1910), p. 39.

2. J. C. G. Röhl, Germany without Bismarck (London, 1967), pp. 45-46; D. Stegmann, Die Erben Bismarcks: Parteien und Verbände in der Spätphase des wilhelminischen Deutschlands; Sammlungspolitik, 1897-1902 (Cologne, 1970), pp. 29-31.

3. A Hohenlohe memorandum in 1898 (after the Reichstag elections) summed up the dilemma: "The election statistics provide irrefutable evidence that it will not be possible in the forseeable future to form a majority from the so-called national parties. One must therefore seek to win over one of the opposition parties. The only party which comes into consideration here is the Center, the overwhelming part of which is monarchist." C. zu 
chancellors depended for their parliamentary majorities on the Center, which in turn showed itself willing to become a "party of government."4

Surprisingly, recent work on the "democratization" of German politics before 1914 has largely passed over the key role of the Center Party. Attention has focused instead on changes within German liberalism and social democracy, and on the related attempts to build a bloc from Bassermann to Bebel, from the National Liberals to the Social Democrats. ${ }^{5}$ Yet there was another potential alignment of Wilhelmine parties, involving the Center: a "Gladstonian coalition"6 of the center-left, formed by the Center, Progressives, and Social Democrats. These parties together had a Reichstag majority at all times after 1890. An alliance formed by them would have exerted serious pressure on the undemocratized political and constitutional systems of the Reich; and given a degree of flexibility among Germany's pre-1914 rulers-which recent writers have suggested was greater than once assumed-such an alliance might have precipitated reforms. The effectiveness of a centerleft alignment was never put to the test prior to 1914, but later events indicated its potential impact. It was, after all, these three parties which moved resolutely in support of Erzberger's 1917 Peace Resolution; and it was their successor parties in the "Weimar Coalition" which became the principal supporters of democratic institutions in the early 1920 . By adhering to an alliance of this kind, the Center itself might have anticipated later events, and developed into the constitutional conservative party within a genuinely parliamentary system which (as the $\mathrm{CDU} / \mathrm{CSU}$ ) it has since become. It chose, however, to join with the Progressives and Social Democrats only sporadically before 1914-in

Hohenlohe, Denkwürdigkeiten der Reichskanzlerzeit, ed. K. A. von Müller (Stuttgart, 1931), pp. 451-53. For earlier calculations by Caprivi leading to the same conclusion, see Röhl, p. 80.

4. R. Morsey, "Die deutschen Katholiken und der Nationalstaat zwischen Kulturkampf und dem ersten Weltkrieg," Historisches Jahrbuch 90 (1970): 31-64.

5. B. Heckart, From Bassermann to Bebel (New Haven, 1974). See also G. Schmidt, “Parlamentarisierung oder 'Präventive Konter-Revolution'? Die deutsche Innenpolitik im Spannungsfeld konservativer Sammlungsbewegung und latenter Reformbestrebungen 1907-1914," in Gerhard A. Ritter, ed., Gesellschaft, Parlament und Regierung: Zur Geschichte des Parlamentarismus in Deutschland (Düsseldorf, 1974), pp. 249-78; and "Innenpolitische Blockbildungen am Vorabend des Ersten Weltkriegs," Das Parlament 20 (1972): 3-32.

6. A. Rosenberg, The Birth of the German Republic, 1871-1918, trans. I. F. D. Morrow (Oxford, 1931), p. 18. 
opposition to the "Big" Military Bill of 1893 , in support of Caprivi's trade treaties, over the Zabern affair. For the most part the Center threw its votes behind the traditional parties of property on the right, and particularly the Conservatives.

This article is an attempt to explain the alignment of the Center. It aims to show, first, some of the resaons why the party at Reich level should have found cooperation with the left, especially with the Social Democrats, so difficult. Secondly, a detailed analysis of the party's political attitudes and policies in one German state, Württemberg, provides a case study by means of which the general arguments put forward can be tested.

The Social Democratic attitude toward the Church was one important obstacle to better relations with the Center. The former regarded religious belief as a private matter, but in practice the party was consistently hostile to the Church, critical both of its teachings and of its social role. The Center had laid the foundations of its formidable political position in the 1870s, in defending the Church and its members against Bismarck's Kulturkampf: while the Social Democrats had not, in fact, supported this assault on the Church, the Center nevertheless viewed Bebel's "State of the Future" (Zukunftsstaat) as suspiciously as it had regarded the "Josephinism" of Bismarck and Falk. In the years after 1890 , Center fears for the autonomy of the Church were kept alive particularly by the constant attacks of both Progressives and Social Democrats on clerical control over education; ${ }^{7}$ and on numerous other issues, from the admissibility of cremation to the sanctity of the family, Social Democratic views crossed those of the Center.

Several points have to be made here, however. First, these differences were no less real in the Weimar Republic, when they did not prevent a substantial measure of cooperation between the two parties. Secondly, the Center was never simply a Catholic or clerical party. The name and program of the party were chosen to attract a broad, nonconfessional following, and a number of Protestants joined the Reichstag group, the most prominent being Ludwig von Gerlach. ${ }^{8}$ At the same time, many

7. See, for example, the Center leader Hertling on the importance of the struggle over education in Prussia: G. von Hertling, Erinnerungen aus meinem Leben, 2 vols. (Munich, 1919-20), 2: 98-99.

8. E. Hüsgen, Ludwig Windthorst (Cologne, 1911), p. 95. 
clerical Catholic politicians spurned the Center at its inception, and other frustrated clerical diehards continued to do so at regular intervals over the years. Even in the early years of its existence the Center stood for more than just Catholic resentment against a two-thirds Protestant state. The party identified itself too with south German opposition to a Prussian-based Reich, and with the dissatisfaction of economically backward regions and social groups at incorporation within a large, dynamic political unit. The support which the Center received from the Protestant Guelphs, backward, traditionalist, and anti-Prussian, is significant; and when party leaders later looked back with distaste on the National Liberal hegemony of the 1870 , it was not only the Kulturkampf they had in mind, but the disturbance of old ways of life by the thrust of industry and commerce unleashed by new and liberal business codes.

Thirdly, relations between the Social Democrats and the Center deteriorated from the 1890 s, at a time when the latter was sloughing off those clerical remnants of its character which remained. With the dismantling of Kulturkampf legislation and the decline in the persecution of Catholics, the Center drew a dwindling return from electoral appeals to confessional loyalty. ${ }^{9}$ The increasing fragility of its hold on Catholics as Catholics was a source of serious concern to party leaders, who began to emphasize the popular, social policies of the Center, and to call for an end to confessional politics. ${ }^{10}$ Support for tariffs and for social legislation like stock exchange controls testified to the growing adherence of Center leaders to a secular Sozialpolitik. The responsiveness of party leaders to popular feeling, and their resistance to the idea of the Center as a clerical party, were brought out by their behavior in 1887 , over Bismarck's Seven Year Military Bill, and in 1893, over Caprivi's "Big" Military Bill. On both occasions the government tried to put pressure on the party, through Rome, to support measures which were unpop-

9. Center leader Porsch, in an 1893 memorandum to Cardinal Kopp, wrote of the declining impact of such appeals: "People now weigh things up much more coolly, where once they followed without thinking," quoted in H. Gottwald, "Zentrum und Imperialismus" (Ph.D diss., University of Jena, 1966), p. 129. Also, T. Nipperdey, Die Organisation der deutschen Parteien vor 1918 (Düsseldorf, 1961), p. 268. On the Center's declining share of the Catholic vote, see below, p. 248 , and n. 78 .

10. It was in this context that Julius Bachem made his famous appeal for a move away from the politics of confessional isolation ("Wir müssen aus dem Turm heraus"). J. Bachem, Erinnerungen eines alten Publizisten und Politikers (Cologne, 1913), pp. 177-95; L. Bergsträsser, Geschichte der politischen Parteien in Deutschland (Munich, 1960), pp. $174-76$. 
ular with the mass of Center voters: on both occasions the Center refused to be swayed by clerical overtures. The line followed by Center leaders brought electoral success, and pointed up the isolated position within the party of clerical intriguers like Archbishop Kopp of Breslau. ${ }^{11}$

It is perhaps worth pointing out the sharp contrast with France, where political Catholicism suffered from the interference of a conservative hierarchy which first delayed Ralliement by its obdurate resistance, and then damned the movement by its support. The respective roles of the parish clergy provide a telling sign of the difference between the two countries. In France, priests who organized the local Catholic peasantry, as in Brittany, were strongly discouraged by the hierarchy, and their efforts were never able to feed the sickly growth of popular social Catholicism. In Germany things were very different. Priests played a major role as local political organizers of the Center party: they sat in state legislatures as spokesmen for small-town interests, acted as unofficial election agents, and-with great attention to the practicalities-ran many of the artisan and peasant associations which did so much to keep these groups within the Center fold. ${ }^{12}$

As parties orientated toward the social question, Center and Social Democrats in fact had much in common. Drawing their support largely from the poorest parts of the population, they formed the two great mass parties in Wilhelmine politics, equipped with the most extensive auxiliary organizations rooted among the people. Significantly, it was in the Center and Social Democratic parties that career politicians like Erzberger and Ebert first rose through the party ranks to achieve prominence. Both parties had suffered under "exceptional legislation," and were opposed to its use; and both, having gained electoral support and

11. Kopp's persistent efforts to swing the Center behind the 1893 military bill were unsuccessful, and when Caprivi asked him to use his position to modify the party's 1893 electoral strategy, Kopp was obliged to admit his lack of influence outside the narrow area of Silesia. See Gottwald, pp. 127-40. In 1898 Hohenlohe also sought to use Kopp to guide Center strategy, and the latter was once again forced to confess his inability to do so. Hohenlohe, pp. 450-51.

12. The Christian Peasant Associations in Württemberg (Anton Keilbach), Baden (Philipp Gerber and Josef Pfaff), and Trier (Georg Dasbach) were organized by priests. The associations arranged for the provision of credit, the purchase of feedstuffs and fertilizer, and the cooperative marketing of crops. They also protected the peasant against the middleman: the Trier association fought over thirteen thousand legal actions against moneylenders and cattle dealers between 1884 and 1918. F. Jacobs, Deutsche Bauernführer (Düsseldorf, 1958), p. 76. 
positions of political power at liberal expense, turned to announce the bankruptcy of liberalism as an economic, political, and cultural force. There was a striking congruence in Social Democratic and Center attacks on German capitalism and in their arguments that the liberal middle class had lost its "progressive" role and forfeited its claim to be considered a "general class." 13

The two parties could agree only in their diagnoses, though, not in the remedies they prescribed, and to explain this requires a closer examination of the kind of popular support which made each a mass party. The question is relatively straightforward in the case of the Social Democrats, who were squarely based on the industrial working class. The Center, by contrast, found some support among all parts of the population, from Rhenish businessmen to Westphalian miners, and from Silesian aristocrats to Bavarian peasants. The fact that it was "a true people's party which embraces all Stände and classes"14 was important to the leaders of the Center: they used it to support their claim that the Center alone was free from the blinkered class and sectional politics of the other parties, whether middle-class National Liberals,

13. The concept of a "general" or "universal" class can be traced back to Hegel, for whom the bureaucracy embodied the general interest of society as a whole (just as the state tended toward the universal). The sense of "general class" intended here is drawn from Marx, who rejected as illusory the Hegelian claim for the universality of the bureaucracy (just as he rejected Hegel's view of the state). Rather, for Marx, different social classes, at particular times in history, succeeded each other in representing the general will and potential of society. Marx, like the German Social Democrats, believed that the bourgeoisie had once represented this "general" interest, but had become the embodiment of partial class rule whose claim to universality had been exploded. It was the proletariat which now inherited the mantle of the "general class." See S. Avineri, The Social and Political Thought of Karl Marx (Cambridge, 1970), chap. 2, pp. 41-64. It is significant that the Social Democrats in Wilhelmine Germany saw in the proletariat not only the general class whose triumph would abolish (aufheben) the contradictions between political power and productive forces, between the state and civil society, etc.: with the supposed onset of the decadent, declining phase of bourgeois liberalism, the proletariat also embodied and subsumed the potential of all society in spheres such as culture. See G. Fülberth, Proletarische Partei und bürgerliche Literatur (Neuwied, 1972), p. 7. On the general problem of the middle class as a general class, $\rightarrow$ A. Briggs, "Middle-Class Consciousness in English Politics, 1780-1846," Past and Present, no. 9 (1956), pp. 65-74. The ideologues of political Catholicism, and Center politicians, could agree with much of the argument that the middle class had lost its former role: they saw the middle years of the nineteenth century as a transitory phase of self-assured liberal bourgeois ascendancy, arrogating to itself (as, for example, in the matter of laissez-faire economic legislation) the claim to embody a general interest.

14. From the 1903 Reichstag election program. L. Bergsträsser, Der politische Katholizismus: Dokumente seiner Entwicklung, 2 vols. (Munich, 1921-23), 2: 330. 
agrarian Conservatives, or working-class Social Democrats; and the existence of this following among different social groups has been remarked on by all historians who have dealt with the party. ${ }^{15}$

The Center did not, however, draw its support evenly from each of these groups. German Catholics at the beginning of the twentieth century remained significantly underrepresented in the great urban areas and in the characteristic occupations of an industrial society. Indeed the "economic backwardness" of Catholic communities was wielded as a confessional weapon by the strongly anti-Catholic Evangelical League, ${ }^{16}$ while Center politicians like the future historian of the party, Karl Bachem, who desperately desired that German Catholicism should break out of the ghetto to which it had been consigned by the Kulturkampf, recognized the realities of the situation when they called for a more active involvement of Catholics in industry and commerce. ${ }^{17}$ The fact remained, though, that in 1912 Catholics, who made up 36.5 percent of Germany's total population, still made up only 25.8 percent of city dwellers, ${ }^{18}$ and were much more heavily represented in the ranks of peasants, artisans, and shopkeepers than among the owners of capital, managers, or the wage- and salary-earning classes. ${ }^{19}$ This was borne out by the areas of Center support, which formed a backward fringe to the south, east, and west of the Reich. The party's strongholds

15. P. Molt, Der Reichstag vor der improvisierten Revolution (Cologne-Opladen, 1963), describes the Center (p. 296) as a "people's party cutting across all classes and interests." For similar judgments, see Bergsträsser, Geschichte der politischen Parteien, p. 191; G. Mann, The History of Germany since 1789 (London, 1968), p. 214; H.-U. Wehler, Das Deutsche Kaiserreich 1871-1918, (Göttingen, 1973), pp. 83-84.

16. J. Forberger, Die wirtschaftliche und kulturelle Rückständigkeit der Katholiken und ihre Ursachen: Flugschriften des Evangelischen Bundes, Heft 263/4 (Leipzig, 1908).

17. This was the crux of a strong speech made by Karl Bachem at the 1901 Annual Catholic Assembly (Katholikentag) in Osnabrück. See also Windthorst's remarks to Adolf Gröber: "The Jews nest happily in Catholic areas, because the Catholics are lazy; our clergy preach too much about the birds and flowers of the field, which do not sow or reap, but yet receive the means to live. This reminds me of something our Bachem said: the Catholic financiers in Cologne have no spirit of enterprise, otherwise they would long since have had control over the whole trade of the Rhineland and Westphalia." H. Cardauns, Adolf Gröber (M.-Gladbach, 1921), p. 43. Comparisons between the backwardness of Catholics and the wealth and drive of Germany's Jewish community were frequently made by Center politicians and publicists, often with overtones of resentment.

18. That is, the population of Grossstädte with over one hundred thousand inhabitants.

19. F. Naumann, Demokratie und Kaisertum (Berlin, 1904), p. 122; J. Rost, Die wirtschaftliche und kulturelle Lage der deutschen Katholiken (Cologne, 1911), pp. 9ff.; M. P. Fogarty, Christian Democracy in Western Europe, 1820-1953 (London, 1957), p. 304. 
were in the rural areas: the Oberpfalz district of Bavaria, along with Schwaben, Oberbayern, and Niederbayern; Oberschwaben, the least industrialized part of Württemberg; the rural areas of the Rhineland around Trier, Aachen, and Cologne; the nonindustrial parts of the Breslau and Oppeln areas in Silesia; and the agricultural Münsterland and Sauerland in Westphalia. Of the 113 Reichstag seats won by the Center and its allies in 1907, 78 were in constituencies where agriculture and small business predominated. ${ }^{20}$

At a time when German political parties were increasingly becoming the vehicles of economic interests, Center and Social Democrats therefore found themselves bound to the support of two mutually antagonistic groups in society: the Social Democrats to the dependent working class of consumers; the Center to the traditional Mittelstand of independent primary producers, petty capitalists, and retailers. The Wilhelmine Center Party was particularly susceptible to the demands of these groups, its claims to stand "above interests" notwithstanding. The declining impact of electoral appeals to confessional loyalty has already been noted. In addition to this, the concentration of Center voters in safe seats (Stammsitzen) was double-edged in its effects: it cut down the cost of fighting elections, but in the absence of serious political opponents it stimulated interest groups to press the party organization for special policies, and even special candidates. The struggle waged by the leadership in the 1890 against agrarian interests within the Westphalian, Rhenish, and Bavarian party organizations demonstrated the power of such groups; $;{ }^{21}$ and as the leadership was hampered by a decentralized party structure and the unreliability of an eccentrically undisciplined Center press, rebels could frequently demand a high price for their loyalty.

The impact of Mittelstand pressure on the Center was evident on a broad range of issues, but especially in the attitude it took up toward agricultural protection; and in this sphere the party necessarily alienated the Social Democrats (and with them, the Progressives), for whom

20. H. Gabler, "Die Entwicklung der Parteien auf landwirtschaftlicher Grundlage von 1871-1912" (Ph.D. diss., University of Berlin, 1934), p. 16, quoted in Gottwald, p. 41.

21. K. Bachem, Vorgeschichte, Geschichte und Politik der deutschen Zentrumspartei, 9 vols. (Cologne, 1927-32), 5: 351-56; Nipperdey, p. 279; F. Jacobs, Von Schorlemer zur Grünen Front (Düsseldorf, 1957), pp. 217ff.; S. R. Tirrell, German Agrarian Politics after Bismarck's Fall (New York, 1951), pp. 120-23, 212-24, 225, 245, 294; K. Müller, "Zentrumspartei und agrarische Bewegung im Rheinland, 1882-1903," in K. Repgen and S. Skalweit, eds., Spiegel der Geschichte: Festgabe für M. Braubach zum 10. April 1964 (Münster, 1964). 
"cheap bread" was a major demand. In the early years of the 1890 s, the Center leader Ernst Lieber was almost driven out of public life, and the existence of the party itself threatened, by agrarian opposition to official Center support for Caprivi's trade treaties, which lowered the tariff protection afforded to primary producers. ${ }^{22}$ The lesson was not lost on the leadership. In subsequent years the Center played a leading role in the passage of legislation which protected dairy producers against the competition of margarine, cattle breeders against imported meat and animals, and all primary producers against foreign competition, by means of the very high Bülow tariff of 1902. When, in 1902, the Social Democrats attempted to block the passage of this measure by filibustering, the Center stood firm alongside the agrarian Conservatives to secure the tariff, and it was the Center deputy Adolf Gröber who was responsible for drafting new standing orders for the Reichstag to prevent a repetition of these Social Democratic tactics. ${ }^{23}$ But even on subjects where Center and Social Democrats were in broad agreement, the former tried to tailor the small print of legislation to the interests of its peasant and small-business supporters. Thus, in supporting improved factory acts and provision for the unemployed, it hoped to turn this legislation to the advantage of the Mittelstand: only large factories, not small workshops, were to be made subject to inspection, giving the artisan producer an advantage over the large capitalist; and the nascent employment exchanges were to be encouraged to divert labor back to the land. ${ }^{24}$ In its economic and social policies generally the Center favored state intervention sufficient to subsidize the independence of the Mittelstand, without expenditure in fields like education and welfare on a scale great enough to harm lower-middle-class taxpayers.

22. Gottwald (pp. 151-52) quotes a letter from Lieber to Heinrich Otto, chairman of the Augustinus-Verein (the association of Center newspapers), complaining of misrepresentation and even of a "war of extermination" (Vernichtungskrieg) being fought against him, and threatening to leave public life completely. Lieber also wrote to the Bavarian Center leader, Schaedler, at this time, deploring the division of the party into economic interest groups, and claiming that this tearing apart of the Center was more advanced than at any time since the Kulturkampf. Lieber to Schaedler, June 6, 1894, Pfälzische Landesbibliothek, Speyer, Ernst Lieber Nachlass, S.32.

23. K. Bachem, 6: 163-65; Cardauns, p. 112. The National Liberals, however, initially supporters of the Center move, later refused to accept a revision of the standing orders.

24. Verhandlungen der Wïrttembergischen Kammer der Abgeordneten auf dem 33 Landtag: Protokoll Band II, p. 1174, 55 Sitzung, June 28, 1895 (henceforth: 33 LT, PB II, p. 1174, 55 S., June 28, 1895); Politische Zeitfragen in Württemberg: Zwanglos erscheinende Hefte 17 (Stuttgart, 1912), pp. 6-9. 
From the early 1890 sittelstand aspirations were firmly incorporated into Center Party policy. This had a crucial bearing on the Center's relations with the Social Democrats, for it occurred at the same time as -although cutting across in its effects-another important change in the Center. At the political level there was a leftward shift in the Center from the early 1890 s, marked by Ernest Lieber's succession to Windthorst as party leader, against the rival claim of Franz Ballestrem, leader of the conservative wing of the party which supported Caprivi's 1893 Military Bill. From the 1893 Reichstag election the conservative aristocrats in the Center declined sharply in numbers and influence, to be replaced by men who, on political issues, stood closer to the Social Democrats, defending unequivocally the ballot box and the powers of the Reichstag against threats to the constitution from the right. If in Prussia the Center continued to resist reform of the reactionary threeclass franchise, there were Center leaders from southern and western states who not only called themselves "democrats," but also joined the left in attacking the tax burden imposed by army and navy expenditure. ${ }^{25}$ Yet, on the crucial matters of economic and social policy these leaders too remained fiercely at odds with the Social Democrats. When contemporaries spoke of a south German left wing emerging in the Center Party before 1914, represented by men such as Heim and Schaedler in Bavaria, Gröber and Erzberger in Württemberg, Fehrenbach and Schüler in Baden, ${ }^{26}$ they were actually observing the growing weight within the party of a strain of pro-Mittelstand radicalism as antipathetic to the working class and Social Democrats as the rigid conservatism of more right-wing leaders like Ballestrem, Porsch, and

25. On the "inner democratization" of the Center, see K. Buchheim, Geschichte der christlichen Parteien in Deutschland (Munich, 1953), p. 221; Morsey, p. 48; Nipperdey, pp. 280 ff. On the south and west German opposition in the Center to the 1893 bill, K. Bachem, 5: 278; Gottwald, pp. 122ff.; and on opposition to the navy, E. Kehr, Schlachtflottenbau und Parteipolitik 1894-1901: Versuch eines Querschnitts durch die innenpolitischen, sozialen und ideologischen Voraussetzungen des deutschen Imperialismus (Berlin, 1930), pp. 43-50, 194-98; K. Bachem, 5: 473-74, 479-80.

26. For an account of the left wing within the party, especially at the time of the Center's disagreement with the government over colonial estimates in 1907, see G. D. Crothers, The German Elections of 1907 (New York, 1941), and K. Epstein, Matthias Erzberger and the Dilemma of German Democracy (Princeton, 1959). After the 1912 elections to the Reichstag, the extreme Conservative Roesicke wrote to von Böcklin (June 2, 1912), expressing his concern that the influence of men like Gröber (who leaned "strongly to the left") was growing, as a result of the frequent absences from Berlin of the conservative Center leader Hertling, who was prime minister in Bavaria, and the ineffectiveness of the Center leader Peter Spahn. Stegmann, p. 324. 
Peter Spahn. In these southern and southwestern states, where Center left and Social Democratic revisionist right might have been expected to meet on common ground, there was in fact little political cooperation prior to 1914. The situation in Baden, where a Social DemocraticNational Liberal Bloc was pitted against a Conservative-Center right, became instead the model for politics in the south, and indeed for the Reich as a whole. ${ }^{27}$

An examination of Center interest groups and economic and social policies in Württemberg provides an opportunity to look more closely at how these affected the party's attitude toward the Social Democrats. Württemberg was in some respects a state known for its distinct political traditions. Celebrated before the nineteenth century for its advanced representative institutions, it enjoyed in the fifty years prior to 1914 the enlightened reign of two monarchs, Karl I and Wilhelm II, who were content to leave policy and politics to their ministers acting together with party leaders. ${ }^{28}$ There was also a long-standing popular democratic tradition in the state, which expressed itself powerfully in 1848 . To the extent that this "anti-governmental" democratic tradition persisted into the second half of the nineteenth century, Württemberg was late in developing a party system based on class lines. This, however, was a feature it had in common with other south German states like Bavaria and Baden.

In other respects, too, Württemberg has claims to be considered representative for a case study of Center-Social Democrat relations. It was one of the south German states where the two conflicting developments which we have noted within the Center from the 1890s-a shift to the left politically, but a hardening pro-Mittelstand position on socio-

27. Heckart, pp. 91ff.; Rosenberg, pp. 48-49; K. Bachem, 8: 145ff. In both Baden and Bavaria the Social Democrats and Center combined over electoral reforms designed to "dish the liberals," the Center gaining in the countryside and the Social Democrats in the towns. But their cooperation did not extend to other issues, and throughout south Germany the Social Democrats found they still had most in common with the National Liberals and Progressives on educational and cultural matters, as on social and economic issues. See H. Schlemmer, "Die Rolle der Sozialdemokratie in den Landtagen Badens und Württembergs und ihr Einfluss auf die Entwicklung der Gesamtpartei zwischen 1890 und 1914," (Ph.D. diss., University of Freiburg, 1953).

28. On the special features of Württemberg, see H. Haering, "Württemberg und das Reich in der Geschichte," Zeitschrift für württembergische Landesgeschichte 7 (1943): 294322; K. Simon, Die württembergischen Demokraten (Stuttgart, 1969), pp. 5-12, 48-49. 
economic issues-were very clear. This was personified in the attitude of the two most important national leaders which the Center party in the state produced, Adolf Gröber and Matthias Erzberger. Württemberg was, at the same time, the only one of these south German states where Catholics, as in the Reich as a whole, made up a minority of onethird. Finally, in the electoral pattern which emerged in the state, of Center strength in the small towns and villages, Social Democrat support in the industrial towns, Württemberg was again representative of German conditions generally.

The parliamentary fortunes of the two parties ran parallel courses in Wuirttemberg. Both won their first Landtag seats in 1895, and continued in subsequent elections to increase their representation at $\mathrm{Na}-$ tional Liberal and Progressive expense. In 1895 the Center had eighteen and the Social Democrats two of the seventy elected members of the Landtag; by 1912 the Center had twenty-six and the Social Democrats seventeen members of an enlarged and all-elected Landtag. But they made inroads into entirely different areas of former National Liberal and Progressive support. The Social Democrats gained in urban working-class centers like Stuttgart, Cannstatt, Esslingen, Geislingen, Göppingen, and Heilbronn; despite attempts to appeal to the rural voter the party could make little headway in such areas. The Center inherited former Progressive voters from among the peasantry and small-business class of the outlying agricultural regions, especially in the extreme south of the state. Its weakness in the towns matched that of the Social Democrats in the countryside. While the ranks of Social Democratic deputies in the Landtag were filled with party functionaries, trade union and cooperative officials, the composition of the Center group in the Landtag gave a clear indication of its Mittelstand pedigree.

Forty-five deputies represented the party in the Landtag between 1895 and the war. Eleven were government officials, who provided most of the party's leadership at state level and in the Landtag itself; seven belonged to the professional middle class (three teachers, two lawyers, two editors); and more than half directly or indirectly represented the interests of the Mittelstand. Nine were small-town mayors, often-like Johannes Sommer (Saulgau) and Georg Maier (Rottweil)themselves artisans or smallholders; a total of five were tavern keepers small businessmen, or artisans; six were peasants; and four were priests, who belonged by birth and upbringing to the rural lower middle class, and one of whom-Anton Keilbach (Waldsee)-was leader of the 
state's Christian Peasant Association (Christlicher Bauernverein). Only three out of forty-five were identified with the interests of large capital or organized labor: two secretaries of workers' associations, elected from the "List" not directly in constituencies; and one factory owner, elected against an official Center candidate and retrospectively accepted into the parliamentary group. ${ }^{29}$ At the local level the mittelständisch character of the party was even more pronounced: at Waldsee the nineman delegation to the party's central state committee consisted of two priests, a teacher, a tavern keeper, a master shoemaker, a painter, a small businessman, and two peasants. ${ }^{30}$

The aim which these interests had in common was to modify the workings of the free-for-all economic system, in order to safeguard their own independent livelihoods. Agricultural producers wanted to resist being pushed into impoverished impotence within a powerful Industriestaat; artisans called for discriminatory legislation against large concerns, which monopolized raw materials and, through economies of scale, enjoyed an inbuilt advantage over the small producer; and retailers wanted tighter controls over the new leviathan department and chain stores, together with their auxiliary services of traveling salesmen, advertising, special offers, and motorized delivery. These groups had begun to turn away from the "Manchester men" of the Progressives when it became clear that this party had little sympathy with the grievances of the Mittelstand. They were no less hostile to the Social Democrats and the organized working class, whose consumer cooperatives pulled down prices, whose trade unions pushed up costs, and whose very existence threatened members of the Mittelstand with the prospect of losing their own independent status. The deftness with which the Center Party appealed to the apprehensions and discontents of these groups had played a large part in creating a popular base for the party

29. Compiled from the Mitgliederverzeichnis for the seven parliaments meeting between 1895 and the war, as contained in $33 L T, B B$ (Beilage-Band) III, pp. 1-4; $33 L T, B B I V$, pp. 419-24; 33 LT, BB IX, pp. 117-19; 34 LT, BB II, pp. 303-306; 34 LT, BB III, pp. 100912; $35 L T, B B I I, p p$. 79ff.; $36 L T, B B I V, p p .455-64 ; 37 L T, B B I I, p p .217 f$; $37 L T, B B$ $V$, pp. 627ff.; $38 L T, B B I V$, pp. 181-84; 38 LT, BB III, pp. 329-55; 39 LT, BB II, pp. 235-42. Further details from the Hauptregister ïber die Verhandlungen der Stände des Königreichs Württemberg und der Landtage von 1856 bis 1906. Center deputies elected at by-elections were traced in the Literarische Beilage des Staats-Anzeigers fïr Württemberg (Chronik des Jahres), where by-election details are given at the end of each annual volume.

30. Waldse'er Wochenblatt, May 5, 1895. 
in Württemberg before $1895:{ }^{31}$ after that date Center leaders had the problem of assimilating and orchestrating the pressures which these voters continued to exert.

The peasantry was a special problem, as rising costs, falling prices, and the unpopular trade treaties combined to heighten rural discontent in the 1890 o. Center leaders were particularly nervous about developments like those in neighboring Bavaria, where the Bayerischer Bauernbund had been formed in 1893 as a radical agrarian party, drawing support from customary Center voters. In Bavaria the effect was to drive the local Center Party further toward the agrarian position, and almost to the point of secession from the national party. ${ }^{32}$ In Württemberg the impact of pressure from agricultural constituencies was similar, if less dramatic. From the outset party leaders faced a strong agrarian wing within the parliamentary group, led by deputies like Theophil Egger (Ravensburg), Franz Xaver Krug (Biberach), and Johannes Sommer. There was a similar tension in the party press, between the Deutsches Volksblatt in Stuttgart, which stood close to the Center leadership, and less staid small-town papers, such as the Ipf-Zeitung, whose sympathies were with the small man on the land and his supporters on the Center back benches. In 1897 back bench impatience over the state of agriculture led to a revolt in the Center Party over tax reform legislation. Agrarian pressure had forced an all-party compromise in the Landtag committee dealing with tax reform, which offered substantial concessions to agriculture and the Mittelstand in the levying of the recast Gewerbesteuer. ${ }^{33}$ But this package, when recommended to the Center group in the Landtag by Viktor Rembold on behalf of the party leadership, was rejected: for many deputies from agricultural constituencies the concessions did not go far enough. An embarrassed Rembold was

31. For a more detailed account, $\rightarrow$ my article, "The Political Alignment of the Centre Party in Wilhelmine Germany: A Study of the Party's Emergence in Nineteenth-century Württemberg," Historical Journal 18 (1975): 821-50.

32. K. Bachem, 5: 294-95; Nipperdey, p. 288. On the hostile temper of peasant opinion generally in Bavaria, K. Möckl, Die Prinzregentenzeit: Gesellschaft und Politik während der Ära des Prinzregenten Luitpold in Bayern (Munich, 1972), pp. 454ff.

33. With the introduction of income tax, the former method of taxing the yield from business now involved an element of "double taxation" on personal earnings from business concerns. The temporary solution found by the Landtag committee was to reduce (by a percentage proportionate to the size of turnover) the scale of liability (Kataster) to tax on businesses (Gewerbesteuer). Agriculture then demanded reductions in the scale of liabilities to tax on land (Grundkataster), their argument based on the falling income from land rather than "double taxation." 


\section{4}

Class and Politics in Wilhelmine Germany

forced to admit in the Landtag that the Center leadership could not carry the party with it. Only after further concessions had been wrung by Center leaders in committee could the deadlock be broken and the support of back bench agrarians once more be relied upon. ${ }^{34}$

The initial response of the leadership to this embarrassment, and to further rumblings within the party as the time for the renewal of Caprivi's trade treaties approached, was to fall back on the traditional claim that the Center must be a party of all classes and Stände, and to warn potential rebels against agrarian blandishments, especially those of the Bauernbund (founded in Württemberg in 1893 as the local organization of the Prussian Junker-dominated Bund der Landwirte). Gröber, addressing the parliamentary group on the eve of the January 1901 election campaign, drew attention pointedly to the dangers of sectional selfishness within the party; ${ }^{35}$ and the care taken over the choice of candidates revealed the determination of the leadership to stamp out incipient interest groups, and select instead men who stood "above the interests." 36

However, the mailed fist policy proved an even greater embarrassment to Center leaders. In Ravensburg they failed to have removed as a candidate the stubborn octogenarian Egger, a focus of agrarian discontent, while in five other constituencies unofficial candidates were up against official Center men, in three cases winning the seat. This serious reverse for the leadership cannot, of course, be ascribed simply to the current of agrarian feeling. In all the constituencies which revolted there was a general feeling of opposition among Center voters in the small towns against high-handed leadership as such. ${ }^{37}$ Another motif of

\section{33 LT, PB VI, 174 S., Dec. 15, 1897; 175 S., Dec. 16, 1897; 179 S., Dec. 22, 1897.}

35. Speech by Gröber at the Europäischer Hof hotel, Stuttgart, reported in the Gmünder Tagblatt, Nov. 11, 1900.

36. In Leutkirch, the local election committee picked Nikolaus Braunger as its candidate rather than the sitting deputy Ferdinand Eggmann, the former having been recommended by Gröber in a letter which spoke of his disinterested talents as a potential member of parliamentary committees (Schwäbische Kronik, Nov. 7, 1900). In Gmünd, where internal squabbles had characterized the party in the 1890 s, the leadership disregarded the claims of both likely local men and settled on an outsider of proven reliability, the Ravensburg lawyer Alfred Rembold, whose brother Viktor was already Landtag deputy for Schwäbisch-Hall, and who was himself an important figure in the Württemberg party, and a member of the Reichstag.

37. In Leutkirch Eggmann was put up against Braunger, and a meeting at Wurzach, attended by over two hundred people, resolved "under no circumstances" to support the leadership's choice. A local man, Eduard Kuen, was put up by constituents in Wangen, and forced the "outsider," member of the Reichstag Theodor Hofmann, to stand down 
discontent was the dissatisfaction which isolated communities felt over the inability of the Center to fulfil its promises to accelerate railway branch line construction: the party had courted the rural Mittelstand vote by attacking Progressive indifference and government neglect in this sphere, and certainly in the constituencies of Gmünd and Tettnang, disillusion at subsequent Center policy seems to have played an important part in the events of $1901 .{ }^{38}$ The branch line issue itself was, however, to a large extent an agrarian issue. Voters in agricultural areas felt a sense of neglect by urban administrators and legislators whom they regarded as acting in the interests of large capital: discrimination against outlying rural areas in the provision of communications was seen as one aspect of this neglect. The agrarian Bund der Landwirte, for example, consistently called on governments to build branch lines rather than main lines and canals. The discontent displayed in Gmünd and Tettnang over the failure of local railway projects must therefore be seen within a broader framework of rural or small-town animus.

In addition other, more specifically agrarian grievances were prominent in 1901. The strength of local feeling on the tariff, rural labor shortage, and other issues was illustrated in Gmünd, where a Bavernbund candidate, Joseph Rupp, polled several hundred votes in Center village strongholds, ${ }^{39}$ while in Horb a smallholder, Franz Kessler, beat

as official candidate. In troubled Gmünd the candidacy of Anton Klaus (the former deputy) was announced against Rembold: "As there is in our district, in truth, no lack of fitting and capable persons, we shall under no circumstances give our votes to anyone other than a resident of the district. ... We oppose categorically the slogan circulated here, that Gmünd must of necessity send off another lawyer to the Landtag, just to provide it with another committee man." If this trend became general, it was argued, the Landtag would degenerate into a "domain of the lawyers, from which may God preserve us." Heuberger Bote, Nov. 17, 1900; Nov. 20, 1900; Nov. 21, 1900; Ipf-Zeitung, Nov. 14, 1900; Gmünder Tagblatt, Nov. 24, 1900.

38. The rebel group in Gmünd contrasted the progress achieved by a railway-conscious deputy in Pforzheim (on the border between Baden and Wuirttemberg) with what they might expect from an outsider in Gmünd, with a lawyer's practice in Ravensburg and political commitments in Berlin. Gmünder Tagblatt, Nov. 28, 1900. On Tettnang, see Schwäbische Kronik, Nov. 4, 1900. At the 1913 by-election in Rottweil, the Progressives tried to make political capital, in turn, out of the Center neglect of branch lines. See the Volkspartei pamphlet "Wahlaufruf an die Wähler von Rottweil," where a "respected citizen" is reported as saying "we are fed up being led around by the nose over our railway by the Rottweil Center party." Copy in the Hauptstaatsarchiv Stuttgart, Nachlass Conrad Haussmann, Q 1/2, 104.

39. The candidate, Joseph Rupp, was sufficiently popular locally to win a place in early 1902 on the committee of the Gmünd Landwirtschaftlicher Bezirksverein. Report 
the official Center candidate on an extreme agrarian program and had to be accepted into the party's parliamentary group..$^{40}$ It was indicated too by the success of a number of official Center candidates like Krug, Sommer, and Joseph Dambacher (Ellwangen), who were demanding firmer measures in the defense of primary producers, including in some cases tariffs even higher than those called for by the Bauernbund.

The shock administered to the leadership in 1901 had its effect. The party strengthened its links with agricultural constituents through the Bauernvereine: Anton Keilbach's entry into the Landtag after a 1904 by-election in Waldsee was one indication of this. The Center also stepped up the demands it made at state level on behalf of agriculture, while the Deutsches Volksblatt became notably more sympathetic to the agrarian cause. The guarding of the party's agrarian flank against the Bauernbund was most evident in the Landtag debates of 1901 over the Bülow tariffs. In the last years of the 1890 os the Center in Württemberg had still been attacking the Bauernbund for the one-sidedness of its demands: now it stole the agrarians' clothes, as it took the initiative in asking the state's representatives in the Bundesrat to press for higher tariffs. One commentator, noting the wholesale appropriation by the Center of the agrarian program, remarked of the debates that by the time Bauernbund deputies were able to speak, "they were, with the best will in the world, unable to present any new points of view, let alone demands of their own."41

Despite competition between the two parties for the peasant vote, Center and Bauernbund Conservatives were drawn together politically by the similarity of their policies after about 1900 . On educational reform, for example, they united against Progressives and Social Democrats, opposing not only the anticlerical tenor of reform plans, but also the proposal to raise the school-leaving age, which would have deprived agriculture of some of its badly needed supply of free family labor. Electoral agreements in by-elections at Münsingen (1903) and Mergentheim (1904) were the first steps toward the formal political

of the association's annual general meeting of Feb. 9, 1902, in Gmünder Tagblatt, Feb. 11, 1902.

40. On the campaign see Schwäbische Kronik, Nov. 24, 1900, and Gmünder Tagblatt, Nov. 16, 1900; and also the Beobachter, Nov. 11, 1901, and Deutsches Volksblatt, Jan. 14, 1901, and Jan. 21, 1901.

41. Tägliche Rundschau (Berlin), Feb. 4, 1901, quoted in Deutsches Volksblatt, Feb. 12, 1901. 
alliance of the 1912 Schwarz-Blau-Block. ${ }^{42}$ As the Center embraced the agrarian Conservatives, its relations with the Social Democrats steadily worsened. In the 1890 s they retained areas of agreement, like support for income tax and antimilitarism; but the reemergence at the turn of the century of the conflict between primary producers and workingclass consumers henceforth overshadowed all other matters on which Center and Social Democrats might have agreed. The Württemberg tariff debates of 1901, like those in the Reichstag, created a bitterness between the two parties which survived until the war. Even in the exceptional circumstances of 1907 , when they were branded together as Reichsfeinde in opposition to Bülow's Conservative-National LiberalProgressive Bloc, the issue of "dear bread" was enough to prevent any alliance at the polls. ${ }^{43}$

\section{III}

While pressure on the Center from agricultural interests has been most commonly noted by historians, the party's relations with other parts of the Mittelstand were equally telling, and important in driving a wedge between it and the Social Democrats. One such group was made up by craftsmen and small businessmen, many of whom like primary producers feared loss of livelihood and independent status as a result of rapid, uncontrolled industrialization. Apprehensions in the business Mittelstand heightened in the last quarter of the nineteenth century, as

42. Both of these were agricultural constituencies. In Münsingen the agrarian Conservatives (Bauernbund) supported the Center candidate, the tavern keeper Schmitt, against the Progressives, who had to field an "agrarian" candidate of their own, Reihling, and play the anticlerical card, to win. In Mergentheim the Center paid off its debt by helping the Bauerbund candidate, Valentin Mittnacht, to victory over the Progressive candidate, Keller. See Politische Zeitfragen, 12 (Stuttgart, 1906), pp. 633-39. The National Liberals (who shared the candidate Keller with the Progressives in Mergentheim) tried to win the Bauernbund away from the pro-Center alliance, and offered a joint candidate. The Bauernbund secretary, Schrempf, refused outright. See the correspondence, printed in Schwäbische Kronik, Nov. 12, 1904.

43. In the Württemberg constituency III (Heilbronn), for example, Center and Conservative agrarians fought together against Progressives, National Liberals, and Social Democrats. K. Jakob, "Landtagswahlen und Reichstagswahlen in Württemberg," Süddeutsche Monatshefte 4 (1907): 517ff.; G. Kittler, Aus dem dritten württemb. ReichstagsWahlkreis: Erinnerungen und Erlebnisse (Heilbronn, 1910), pp. 142-43; Th. Heuss, Erinnerungen 1905-1933 (Tübingen, 1963), pp. 59-64. In 1908, while the Bloc still existed, the major political alignment remained-as in Baden-a Conservative/Center agrarian right against a Social Democrat/Progressive/National Liberal left. See, for example, the lineup in the municipal elections in Stuttgart and Neckarsulm, Deutsches Volksblatt, Jan. 17, 1908. 
the liberal economic codes of the unified Reich, together with the fillip given to large-scale industrial expansion by a larger market, presented them with serious competition. By 1890 new industrial processes and changing patterns of consumption had already gravely undermined groups of craftsmen like coopers, tanners, and nailmakers; and small producers in major branches such as construction, metalworking, and food and drink were now concerned at the disadvantages in acquiring capital, labor, raw materials, and outlets which they faced when competing with larger concerns. ${ }^{44}$

In Württemberg small businesses had been struggling against factory competition and the decline of traditional corporate controls since the first half of the century. Nearly six thousand artisans' businesses were subject to forced sales in the eight years after $1840,{ }^{45}$ and the National Artisan Congress at Frankfurt in 1848 received countless petitions from the state calling for the abolition of liberal industrial codes which supposedly discriminated against the Mittelstand producer. One from Tuttlingen, for example, praised the old guild system and protested emphatically against "the trade freedom (Gewerbefreiheit), which is nonsensical in our situation, but which so many progressive men profess." 46 As in the Reich generally, the more rapidly proceeding industrialization which occurred after mid-century aggravated the situation. In Württemberg, a state with strong craft traditions, a number of notable men succeeded in coming to terms with the new circumstances: Gottfried Daimler, who began his career as a simple gunsmith; Ernst Junghans, a master watchmaker whose entrepreneurial talents secured him worldwide markets for an expanded business; and Karl Voigt, whose locksmith's workshop grew to the point where it was capable of supplying Niagara Falls with its turbine engines. ${ }^{47}$ But such men remained ex-

44. J. Wernicke, Kapitalismus und Mittelstandspolitik (Jena, 1922), pp. 143-47; A. Noll, "Wirtschaftliche und soziale Entwicklung des Handwerks in der zweiten Phase der Industrialisierung," in W. Rüegg and O. Neuloh, eds., Zur soziologischen Theorie und Analyse des 19. Jahrhunderts (Göttingen, 1971), pp. 201-5.

45. Wïrttembergische Jahrbiicher (Stuttgart, 1847), pp. 179ff. Well over a thousand tradesmen and tavern keepers also had their businesses forcibly sold off in the same period.

46. Schwäbische Kronik, 1848, p. 1130; T. Schnurre, Die württembergischen Abgeordneten in der konstituirenden deutschen Nationalversammlung zu Frankfurt am Main (Stuttgart, 1912), p. 9.

47. See W. Zorn, "Typen und Entwicklungskräfte deutschen Unternehmertums," in K. E. Born, ed., Moderne deutsche Wirtschaftsgeschichte (Cologne, 1966), pp. 36, 429; W. Ehmer, Südwestdeutschland als Einheit und Wirtschaftsraum (Stuttgart, 1930), pp. 48-49, 55 . 
ceptions. Many reconciled themselves to a drop into the wage-earning proletariat, or-as lowly Alleinmeister-to a position where they were no better than wage earners, delivering standardized goods to the factory or retailer rather than direct to the customer, while those who continued to struggle against the growing concentration of production and a shortage of capital looked to the political parties for special protection. The continuing importance of agriculture in Catholic areas enabled an especially large number of small crafts to maintain marginal existences on local peasant custom.

Prior to 1895 the Center had made a strong appeal to these men, and in subsequent years it sought on their behalf a positive, interventionist state role in the economy, with the use of fiscal and other levers to modify the terms on which large and small concerns competed. It responded to the demands of the artisan workshops by helping to bring about a change in the bidding system used by public authorities, so that large firms with the lowest bids were not automatically awarded contracts; and it welcomed the introduction in Württemberg of the 1897 Reich law partially restoring the guild system, which it had itself helped to pilot through the Reichstag with Conservative support. The object in both cases was to confer on the craftsman special protection against the impact of competition in the free market; and the same intention underlay support for Württemberg's master bookbinders, who were trying to maintain their craft monopoly in the binding of schoolbooks, hymnbooks, and religious calendars against interlopers such as schoolteachers, school inspectors, and sacristans. ${ }^{48}$

Characteristic of the Center's solicitude for Mittelstand concerns was the attempt to prop up the traditional brewing industry in the state. In this branch of production concentration was far advanced, the market dominated by a number of large firms utilizing technical innovations beyond the reach of the smaller brewer. ${ }^{49}$ The Center electorate in-

\section{Politische Zeitfragen, 4 (Stuttgart, 1900), pp. 199-200.}

49. Sophisticated brewery equipment, such as copper cooling vats, was manufactured in Württemberg and found large markets overseas, including the U.S.A. The Feuerbach suburb of Stuttgart was a major center. See Klein, "Industrie und Handel. Bergbau," in V. Bruns, ed., Württemberg unter der Regierung König Wilhelms II (Stuttgart, 1916), p. 818. On large Stuttgart brewing cartels, like the Siegelberger Aktienbrauerei-Wulle group, with a combined share capital in 1906 of 3.75 million Marks, see the report in Deutsches Volksblatt, Dec. 3, 1906. On the parallel movements toward concentration in Bavaria, W. Zorn, Kleine Wirtschafts- und Sozialgeschichte Bayerns, 1806-1933 (Munich-Pasing, 1962), pp. 47, 53 . 
cluded two important groups who wanted to see the taxation system altered in their favor. There were, first, the family brewers, peasants or artisans with a small plot of land, who produced enough beer domestically for their own needs, with a little extra. In the party heartland of Oberschwaben there were 700 such family brewers in Adolf Gröber's constituency, Riedlingen; 556 in Biberach; and 372 in Leutkirch. Two other predominantly Catholic areas represented by the Center contained the largest number of family brewers in the state: Neresheim, with over 700, and Ellwangen, with more than 1,000.50 The main area of concern for this group was the lack of exemption in the malt tax for Weissbier, the main domestically brewed beer. The second group was that of medium-sized businesses who were finding it difficult to survive in competition with large rivals. In Ehingen, for example, where "beer brewing [had] always been an important concern," an official report recorded a large drop in the number of independent breweries in the course of the nineteenth century. ${ }^{51}$ The main demand from this interest was for favorable differentials in the incidence of the malt tax, and a ban in the preparation of beer on the use of surrogates like rice, which afforded advantages of cost over malt barley, but only to the large enterprises which could raise the initial capital to invest in their application. ${ }^{52}$

Center deputies from the constituencies involved were active in bringing these grievances before the Landtag. In 1895 a Center bill incorporating the brewers' demands, and an interpellation of the government along the same lines, were instrumental in the drawing up of a government bill, strongly supported by the Center, which banned malt surrogates entirely, and fixed a scale of tax liability advantageous to middle-sized concerns. ${ }^{53}$ In the years up to 1906 the party could claim with justification that its efforts had slowed down the "swallowing up of small concerns" (der gewerbliche Aufsaugungsprozess): in that time the number of breweries diminished by only 287 , compared with a figure

50. See the speech of Kaspar Vogler, Center deputy for Neresheim, 33 LT, PB II, pp. 1071-72, 50 S., June 21, 1895; and on the traditional strength of brewing in the Laupheim and Waldsee areas, E. Schwab, P. Weiss, K. Holtermann, et al., 100 Jahre Obersc'iwäbische Industrie- und Handelskammer Ravensburg 1867-1967 (Ravensburg, 1967), p. 157.

51. Das Königreich Württemberg: Eine Beschreibung nach Kreisen, Oberämtern und Gemeinden. Herausgegeben von dem K. Statistischen Landesamt, 4 vols. (Stuttgart, 1904), 4: 97.

52. For the brewers' demands, see the report of the 1899 annual general meeting of the Württemberg brewers in Biberach, Ipf-Zeitung, June 7, 1899.

53. Motion of Dentler (Wangen), to ban malt surrogates, 33 LT, BB III, p. 529, Beilage 5; Initiativantrag Vogler und Genossen, 33 LT, BB III, p. 491, Beilage 42 (on the malt tax); and Kiene's interpellation, $33 L T, B B I X, p .3232$. 
of 463 in the same length of time prior to the introduction of the new law in $1899 .{ }^{54}$ In 1909 , when tax levels in the state had to be adjusted to new Reich financial reforms, and both government and Landtag committee (led by committee reporter, Social Democrat Lindemann) decided to remove the differentials, it was the Center which led theeventually unsuccessful—opposition in committee and on the floor of the lower house. .5

In the measures by which it sought to protect the independent artisan or brewer, the Center not only ran up against Progressive believers in the unfettered development of industry and commerce. Like the Progressives, the Social Democrats viewed the small man as an outmoded figure from a preindustrial era, doomed to extinction in the struggle against larger, more competitive rivals, and vainly trying to turn the clock back by appealing to the government for special privileges. It opposed attempts to create sheltered enclaves where inefficient and marginal producers could resist the effects of the market; and on all issues of this kind it aligned itself unequivocally with the Progressives and the captains of industry who provided so many of their leaders.

Center and Social Democrats were also divided on the conflict within the workshop itself, between master craftsmen on the one hand, journeymen and apprentices on the other. At the root of the Center's critique of capitalist society lay hostility to the idea of the necessity of class conflict, symbolized for the party by the industrial code of the new Reich (operative in the individual states), which replaced the terms "master" and "journeyman" with those of "employer" and "employee." In trying to preserve the independent artisan, the Center was led into a vigorous attack on the idea of "trade freedom," which it said had disrupted and undermined the old, harmonious relations of the workshop. ${ }^{56}$ But the trade freedom which, as we have seen, was attacked by artisans even before 1848 , and which the Center consistently opposed, had in fact provided an opportunity for numerous journeymen and apprentices to escape from the tutelage of their masters, and establish their own businesses; or, alternatively, to enter the ranks of

54. 37 LT, PB VI, p. 6167, 227 S., Aug. 9, 1909.

55. In committee the party repeated the demand of family brewers for exemption, and asked for a 10 percent reduction in the malt tax for producers in the $250-500 \mathrm{dz}$. band. 37 LT, BB VII, p. 70, Beilage 433.

56. A very typical statement of this case is to be found in the article "Zur Handwerkerfrage," Waldse'er Wochenblatt, Dec. 3, 1895. 
skilled workers and repairers, selling their labor on the market at better rates than they had enjoyed before. ${ }^{57}$ The policy of the Center made little appeal to either of these groups. Those who had set themselves up independently would, in many cases, have been willing to join the artisan cooperatives advocated by the Center, but ventures of this kind usually foundered on the reluctance of the larger, established masters to share their resources. ${ }^{58}$ Meanwhile, for flouting the authority of guild and master, the newcomers, like those who had identified themselves with the skilled working class, often found themselves castigated by the Center for disloyalty to the Handwerkerstand. When the party spoke for the interests of the artisan, it was very much master craftsmen it had in mind. The legislation of 1897 was aimed at restoring some of the paternalistic discipline and self-government within the guild which had been abandoned in the business codes and practices of the previous three decades, while the introduction of the Befähigungsnachweis ${ }^{59}$ improved the position of masters at the cost of closing the door on the ambitions of journeymen and apprentices.

In Württemberg, as in the Reich generally, the relations between masters and men in the years after 1890 were frequently worse in small workshops than in larger factories. At the purely tactical level, trade

57. With the rising consumption of such articles as household furniture and fittings, bicycles, clocks, and watches, the scope for repairs was never greater. There were also many examples of artisans who had accepted a position as skilled outworkers for large concerns and relinquished ideas of "independence." Wilhelm Keil, later Social Democratic leader in Württemberg, served in his youth as an apprentice under one such Zwischenmeister near Hamburg, who produced only ladies' umbrella handles. W. Fischer, Quellen zur Geschichte des deutschen Handwerks (Göttingen, 1957), p. 171. The raw materials were delivered, and the finished articles collected, by a wholesaler. Theodor Heuss spent six weeks of a school holiday in Heilbronn working with a carpenter whose workshop turned out cupboards for a large furniture store. Th. Heuss, Preludes to Life: Early Memoirs, trans. M. Bullock (London, 1955), p. 87.

58. H. Crüger, Vortag über gewerbliches Genossenschaftswesen, Warenbazare und Grosswarenhändler gehalten auf dem 41. Verbandstag Württ. Gewerbevereins in Calw im Oktober 1899 (Stuttgart, 1899), p. 28; A. Gemming, Das Handwerkergenossenschaftswesen in Wiirttemberg (Stuttgart, 1911), p. 82.

59. The revision of the Reichsgewerbeordnung (RGO) in 1897 did not go far enough for many in the artisan movement, who continued to demand changes in Article 129 of the RGO which would allow only those with the title of "master" to supervise apprentices. This change-the so-called kleiner Befähigungsnachweis-became law in 1908: it represented a significant move away from the concept of freedom of trade, although it still failed to satisfy extreme artisan demands. See Wernicke, pp. 834ff.; E. Aufmkolk, "Die gewerbliche Mittelstandspolitik des Reiches (unter besonderer Berücksichtigung der Nachkriegszeit," (Inaugural diss., University of Münster, 1930), pp. 15-16. 
union organizers could see the advantage of undertaking industrial action against smaller employers who lacked the resources to resist a prolonged dispute. But there were deeper reasons for this situation: on the one hand, employees in the workshop resented the long hours, low wages, and heavy-handed discipline which were so characteristic; while, on the other hand, the masters complained that technical education, provided by the municipalities at special courses, was robbing them of their supply of labor at critical times, as well as helping to spirit the young men away to the factories. ${ }^{60}$ If, in these disputes, the Center usually took the side of the master, and hoped to resurrect the unity and "fellowship" of the workshop under his control, the Social Democrats made great headway among journeymen and apprentices, to whom the traditional guild system had little to offer. Again, even among those who were masters, there were enormous differences: the Center addressed itself to those who were determined to retain their sense of independence and Mittelstand status, while for those who had reconciled themselves to a situation which was effectively proletarian, especially the struggling Alleinmeister, the Social Democrats were often probably more attractive. Once again, the line of division between Center and Social Democrats was between those who regarded themselves as members of the Mittelstand and those who were beginning to see themselves primarily as working class. ${ }^{61}$

\section{IV}

The third branch of the Mittelstand whose interests helped to determine the shape of Center policy was that made up by retailers; and few

60. On disaffection and indiscipline among apprentices and journeymen, F. Gerhardt, "Gewerbe und Handwerk," in Bruns, pp. 867-68. Representative complaints among masters on the schemes whereby apprentices were released from work to attend government-sponsored courses in technical education and so on, as well as on the bidding system, were aired at the 1904 annual general meeting of the Rottenburg Gewerbeverein, reported in the Neckar-Bote, Mar. 1, 1904.

61. It is important not to take the claims of the Mittelstandspolitiker at face value, and assume that artisans-the Handwerkerstand-constituted a harmonious, homogeneous group. Quite apart from the unmistakable evidence of growing class conflict in the workshop, between masters and men, there was also a growing differentiation between larger and smaller independent artisans. While the Center (like the Conservatives and AntiSemites) appealed to those artisans who kept up the struggle for standesgemäss respectability, many of those who had been reduced to indigence drew the political conclusion that their future lay in identifying with the industrial working class and the SPD. See my article, "The Mittelstand in German Society and Politics, 1871-1914," Social History, no. 4 (1977), pp. 409-33. 
groups were more vociferous. As early as 1895 , for example, the Center candidate in Waldsee, Anton Beutel, was faced with special demands from the highly organized butchers and bakers, ${ }^{62}$ as well as from tavern keepers looking for repeal of a special tax levied in Württemberg on sales of wine (the Umgeld). The Center press deplored this rash of interest politics, and Beutel used the columns of the Waldse'er Wochenblatt to explain why he could not at that stage accede to the tavern keepers' wishes. ${ }^{63}$ But the issue was sufficiently sensitive for the party to take two representatives of the interest into the parliamentary group, and to take up another of their complaints-the sale of bottled beer by non-tavern keepers.

Shopkeepers did particularly well out of the Center. Legislative restrictions on the sales methods of large retail concerns were passed in the Reichstag with Center and Conservative support, in a law which substantially enlarged the concept of "unfair competition" (Unlauterer Wettbewerb). When this failed to quell the flood of local complaints about advertising, free offers, and the ubiquitous traveling salesmen with their order books, ${ }^{64}$ the Center ran a vigorous press campaign on the evils of modern commercial methods, and took up the issue at state level. It interpellated the government for statistics on the abuse of the law, asking that the available powers be more widely used, and divided the Landtag on a motion calling on the Württemberg delegation in the Bundesrat to move for even tighter restrictions on traveling salesmenthe "itinerants in patent leather shoes" 65 who had replaced the traditional pedlars and hawkers as the scourge of the respectable small family business. Here, as in many other spheres, the conservative morality of Center politicians reinforced, and was reinforced by, the economic interests of the party's followers. The large concerns which sent out representatives were also directly penalized in Württemberg as a result

62. Of the fifty-six producer and sales cooperatives which existed in Württemberg by 1907, twenty-five were accounted for by butchers and bakers. There had been a butchers' cooperative in Stuttgart as early as 1874. L. Dessauer, "Die Industrialisierung von GrossStuttgart" (Ph.D. diss., University of Tübingen, 1916), p. 58. On the bakers, see also Crüger, p. 24.

63. Waldse'er Wochenblatt, Jan. 26, 1895.

64. For four examples among many, see Waldse'er Wochenblatt, Feb. 13, 1897 ("Vom Oberland, Feb. 6"), and Apr. 7, 1898 (report of Gewerbeverein meeting); Ipf-Zeitung, June 14, 1899 (report of Gewerbeverein meeting), and June 2, 1900 (Rottweil Handelskammer meeting).

65. The phrase is that of Center deputy Karl Walter, 37 LT, PB I, p. 621, 26 S., May 17, 1907. 
of Center efforts: after years of lobbying, the party succeeded in bringing onto the statute books a progressive tax on the turnover of all stores and companies with subsidiary branches. As a further step to alleviate the difficulties of small shopkeepers, the Center deputy Schick introduced a bill, with official party backing, the passing of which enabled the removal from station platforms of automatic vending machines, a serious irritant to local tradesmen. Its implementation led to the removal of machines from 116 sites. 66

The class of small shopkeepers which the Center was trying so assiduously to keep afloat was swollen in Württemberg-as in every other state- by the continual entry into it of artisans who had been squeezed out of the productive sector of the economy. For many, ownership of an inn or grocer's shop represented a last, desperate attempt to salvage Mittelstand respectability and avoid the drop into the ranks of wage and salary earners. Unfortunately this exodus into petty retailing made little economic sense. Even the Center, which defended the survival of a large Mittelstand on social grounds, admitted that the body of small retailers contained a large penumbra of inefficient members. ${ }^{67}$ That many were chronically uncompetitive was tacitly conceded when the party press was obliged to fulminate against other members of the Mittelstand who chose to shop at the department and chain stores because of the price advantages they offered. ${ }^{68}$ Shopkeepers who traveled into the towns, bought up department store stock, and resold it at a higher price in the small towns underlined this point even more. ${ }^{69}$ The long-term solution advocated by the Center was to encourage shopkeepers, like artisans, to pool their resources in sales cooperatives. These efforts, in fact, were largely a failure: disunity, shortage of starting capital, and trade jealousy inhibited the growth of such cooperatives among shopkeepers even more than among artisans. But there can be little doubt that where they were successful—especially among butchers and bakers -the result, anyway, was higher prices for the consumer. In Schramberg, for example, a bakers' cooperative was reported as being so successful that it "prepared the way for a rise in prices which would not

66. Politische Zeitfragen, 4 (Stuttgart, 1900), p. 180.

67. See Kiene's speech, 35 LT, PB IV, p. 2678, 122 S., July 5, 1902. The Ipf-Zeitung also stressed this point when it carried (May 19, 1899) a summary of a Hanover Chamber of Commerce report on the dangerous mushrooming of small retail concerns in all parts of Germany.

68. See Ipf-Zeitung, Mar. 20, 1899 ("Viel mehr zusammenhalten").

69. 35 LT, PB IV, p. 2695, 123 S., July 8, 1902. 


\section{Class and Politics in Wilhelmine Germany}

have been possible for the individual [baker]."70 It was hardly surprising, therefore, that the Social Democrats also sided here with the Progressives against the Center, in defending the advantages of the large stores and attacking those who raised the price of goods in the shop. Karl Kloss, Social Democratic deputy for Stuttgart, singled out the bakers for special attention, as a group by whom the working-class consumer was "milked in an outrageous way."71

It was the bakers, too, who were prominent in the clash between the Mittelstand shopkeepers and working-class consumer cooperatives in Württemberg, a struggle which also embroiled Center and Social Democrats on opposite sides. The cooperative movement in the state had two distinct wings: the producer and sales cooperatives (including peasant cooperative ventures) of the independent Mittelstand, which grew out of the efforts of Schulze-Delitzsch; and the cooperatives of the working and white-collar classes, pioneered in Württemberg by Eduard Pfeiffer. ${ }^{72}$ In the early years the two had worked uneasily together within the same umbrella organization, but as a more clearly differentiated class society emerged, the conflict between producer and consumer grew sharper and the pressure increased for a formal separation of the two wings. In 1902 the Reich consumer movement seceded and began to grow rapidly in size. By 1913 it had one hundred thousand members in Württemberg, and had moved from its original distributory role to become a large-scale producer in its own right, especially of bread, other foodstuffs, and shoes. ${ }^{73}$ Early German socialists like Lassalle had been suspicious of the kleinbürgerlich character of the cooperative movement; but the split of 1902 quickened an already growing Social Democratic interest in the consumer cooperatives, and led to an in-

70. Gemming, p. 79.

71. 33 LT, PB III, p. 1736, 80 S., May 9, 1895.

72. On the difference in character of the two wings, see K. Bittel, Eduard Pfeiffer und die deutsche Konsumgenossenschaftsbewegung: Schriften des Vereins für Sozialpolitik, Untersuchungen über Konsumvereine, 151/1 (Munich and Leipzig, 1915), p. 101.

73. On membership figures, see F. Feuerstein, Geschichte des Verbandes württembergischer Konsumvereine 1904-1929 (Stuttgart, 1929), p. 14. In 1889 the Stuttgart cooperative had fifteen food shops, in 1914 thirty-eight. In 1902 it opened its first shoe shop and added a second in 1908. But its bakery showed the most spectacular expansion: in 1900 the new, enlarged premises on the Schlosserstrasse were using 1.8 million $\mathrm{kg}$. of flour annually; by 1905 this had risen to 2.8 million, and by 1913 to 4 million. E. Hasselmann, Und trug hundertfältiger Frucht: Ein Jahrhundert konsumgenossensch. Selbsthilfe in Stuttgart (Stuttgart, 1964), pp. 71-72, 77. 
creasing interlocking of socialist party and cooperative movement. ${ }^{74}$ To socialists like the Social Democratic deputy and consumer cooperative chairman in Württemberg, Franz Feuerstein, the organization, like the trade unions, provided evidence of the increasing self-confidence and strength of those "consuming masses" who had been reduced to selling their labor. ${ }^{75}$

The scale of cooperative turnover soon provoked opposition from the Mittelstand: the working-class cooperative became for petty retailers a symbol of their oppression as potent as the Jewish-owned department store. In Württemberg the Schutzverein für Gewerbe und Handel, the Artisan Chambers, and especially the bakers' association (the Bäckerverband) were active petitioning the government, running press campaigns, and lobbying sympathetic parties in order to achieve a curtailment of cooperative business. ${ }^{76}$ The Conservatives supported these demands; and the Center, so diligent in its efforts to establish cooperatives among peasants, artisans, and shopkeepers, was a consistent supporter of measures designed to obstruct the consumer branch. In 1896 Center and Conservatives obtained certain legal restrictions on their operations, and in the following years the two parties worked together in the Württemberg Landtag to broaden the campaign. No less than agricultural tariffs, this issue pointed up the conflict between the Mittelstandorientated Center and the working class-based Social Democrats.

An examination of the Center Party's economic and social policies in Württemberg between 1895 and 1914 suggests, therefore, a pattern similar to that obtaining in the Reich generally. Having mobilized politically the peasant, small-business, and retailing Mittelstand, the Center found itself committed to a range of policies on agricultural tariffs, the reintroduction of the guild system, changes in the bidding

74. The growing acceptance by the SPD of the political role of the consumer cooperatives had sound doctrinal support from Marx, who at Geneva in 1865 praised the movement as an important stage in the development of working-class consciousness. F. Feuerstein, Denkschrift über die Bedeutung des Genossenschaftswesens für die Entwicklung der Gemeindewirtschaft: Mit besonderer Berücksichtigung der Konsumgenossenschaften (Stuttgart, 1920), pp. 21-22.

75. Feuerstein, Geschichte, p. 4.

76. Hasselmann, p. 68; Feuerstein, Geschichte, p. 4. In 1912 the Württemberg Schutzverein organized a boycott of the candidates from parties which had refused to support its demands. Deutsches Volksblatt, Nov. 4, 1912. 
system, department store and consumer cooperative taxation, all of which tended to shelter the small producer or distributor at the expense of the consumer, who was obliged to pay a higher price for the goods he purchased. Whatever agreement might have existed in other political or constitutional areas, this Center policy was bound to antagonize the left, and especially the Social Democrats.

One consequence of Center Mittelstandspolitik at the Reich level was a striking loss of support for the party among the Catholic working class, to which it offered the crumbs of its economic and social policy, and nothing that was not available from the Social Democrats. In the bargaining over the Bülow tariffs, for example, the Center hoped to mollify Catholic workers by setting aside some of the revenue from meat, rye, and wheat duties for a widows' and orphans' insurance scheme. But, as Progressive deputy Roesicke pointed out, 600 million Marks was being taken from consumers, and only 78 million Marks returned to this fund. ${ }^{77}$ The idea-taken from "agrarian" academic Adolph Wagner-was mere window dressing: it proved a complete failure, and a comprehensive insurance scheme had to be introduced in 1911. By 1912 the Center proportion of total votes cast at Reichstag elections had fallen from 27.9 percent in 1874 to 16.4 percent, its share of the Catholic vote from the Kulturkampf high-point of 83 percent to 54.6 percent. ${ }^{78}$ Most of this loss consisted of desertions among the Catholic working class. After the 1912 election, which the Center fought in close alliance with the Conservatives in defence of the agrarian finance reforms of 1909, the party had retained only Augsburg, Essen, Krefeld, MönchenGladbach, Aachen, and Münster of the large urban-industrial constituncies it had formerly held: Cologne, Munich, Würzburg, Strassburg, Düsseldorf, Mainz, Metz, and Mülhausen had all been lost to the Social Democrats.

It would be wrong, however, to see this neglect of Catholic workingclass interests solely as an effect of pressure-group demands on the Cen-

77. K. D. Barkin, The Controversy over German Industrialization 1890-1902 (Chicago, 1970), p. 239.

78. That the Center was able to obtain a regular hundred Reichstag deputies at a time when its share of the poll was declining was the result of two factors: the concentration of the Catholic electorate in compact areas; and (more important) the favoring of rural and small-town areas by a division of constituencies which remained unchanged from 1871 to 1914 . Thus the party enjoyed about a quarter more seats in the Wilhelmine Reichstag than it would have obtained under a proportional representation system such as operated in the Weimar Republic. J. Schauff, Die deutschen Katholiken und die Zentrumspartei (Cologne, 1928), pp. 20-23. 
ter. Although it made sense electorally to satisfy those interests which were most strongly represented among its supporters, those responsible for formulating party policy also had a prior concern with the survival of a strong Mittelstand. While eschewing the rabidly antiindustrial stance of the agrarian right, the Center leadership was alarmed at the social and moral ferment which accompanied industrialization. They did not believe that preindustrial economic and social relations could be reconstituted, but they would have liked to arrest the rapid development of German society, prevent the war of "all against all," and encourage every man to be a contented member of his own Stand. The Mittelstand of moderately prosperous, frugal, and independent men was therefore of great symbolic importance to the Center. If nurtured, it would supposedly act as a healthy bulwark against both the extravagances of plutocracy and the dangerous, revolutionary urges of a "dependent" working class with no real stake in the social order. ${ }^{79}$ In effect, Center politicians endowed the Mittelstand with the qualities of a general class.

In this, too, the Social Democrats and Center were at odds. For the Social Democrats had, in the proletariat, their own general class. While the Center saw the worker as a degraded artisan, the Social Democrats viewed the artisan as a potential proletarian. In Wilhelmine Germany the struggle was joined between the two, not only over the representation of different interests, but over rival conceptions of how society was to develop. Only with the coming of the Weimar Republic was this conflict tempered. The Social Democrats found the clerical worker deaf to their entreaties, unwilling to consider himself a black-coated species of proletarian; and the "two-fifths barrier" undercut the idea of a proletarian general class at the polls. The Center, viewing the same phenomenon from an opposite angle, could see that the clerical worker it had often formerly despised for his "dependence" was in fact reliably conservative in his social attitudes; and a growth of party organization among black-coated workers was one result of this realization. In the Wilhelmine political arena, however, Social Democrats and Center faced each other across a starker divide, the one as buoyant champion of the working class, the other as defiant defender of the Mittelstand.

79. It was on these grounds that Gröber justified Center support for the payment of Reichstag deputies: "One should above all be concerned with the Mittelstand, which has not received the representation it deserves" (Molt, pp. 43-44, n. 16). In its programs, political statements, and in debates and the party press, the Center took as a principal starting point of its policy the need for the "preservation of a healthy Mittelstand." 